\title{
The Secret Knowledge of Folk Healers in Macedonian Traditional Culture
}

\author{
Vesna Petreska \\ Institute of Folklore "Marko Cepenkov" \\ Skopje, R. Macedonia
}

In Macedonian traditional culture the concept of "witchcraft", is on the one hand connected to the supernatural world, i.e. with supernatural beings, but on the other hand, it is connected to the ordinary people of this world. The witchcraft which is connected to the supernatural world usually occurs at night or at the borders between night and day. In terms of space, it most often takes place near boundaries, that is at the edge of or outside the village, in the forest, near water. Thus, people who find themselves in a forbidden place at the wrong time of day can be punished by these supernatural beings. The following are demonic beings in Macedonian traditional culture that occupy liminal places: самовили - in people's beliefs they are imagined as invisible, very beautiful women, with long hair and dressed in long white shirts, demons of fate (наречници, нави), vampires (вампири), ghosts (каракониул/ каракониула), and demonic personifications of illnesses (чума, колера/ кулера, треска, etc.). The second category of witchcraft is connected to the ordinary people of this world, i.e. "social" beings. In traditional culture, all aspects of people's lives, their illnesses, unexpected deaths, and their successes and failures were believed to be the result of the work of magic. Accordingly, there are entire sets of terms to distinguish those people who are able to cast "spells", and they are known as witches маѓешници, маѓосници, мамници, презимачки, вештерки аnd those who are able to "break" them, known as healers, spell-chasers, fortunetellers, conjurers - бајачи/ки, народни исцелители, кушачки, etc.

On the territory of Macedonia, the greatest condemnation was reserved for spells put on people's health and life, which were the most important values in traditional culture. The next level of condemnation fell upon the magical appropriation of corn or milk, the two most profitable branches of traditional economy. In Macedonia, the people who "perform" magic were believed to be exclusively women. There are no folk narratives about men doing magic, though such are known in many parts of the world. Also, in Macedonian lexicology, the terms reserved for those who cast spells are always feminine: маѓешница/u, маѓосница/и, мамница/и, презимачка/и, вештера/ки еtс. The 
following outcomes have been attributed to spells: terrible diseases, unexpected death, especially of those who were known to be of good health, the death of newborns, male impotency, female infertility, marital disputes that lead to indifference and hatred, poor harvest, bad cow's or sheep's milk, or unsuccessful farming, and disputes in the life of a family that had suffered failure in several of their undertakings or transactions. This shows that, in Macedonia, not only are many diseases attributed to the influence of the supernatural, but, in the mind-set of the community, supernatural forces directed by social enemies are believed to be responsible for a whole series of negative outcomes [Mencej 64].

The "madjosnica" witches do not possess demonic or mythical qualities. They are women from the village or surrounding areas who are envious or malicious simply because the community perceives them to be that way. They are believed to cast spells and perform magic and it is said that they will go to hell after they die. These are women who personify social tension among families and neighboring villages and are considered by E. Pócs to be "neighbouring witches" or "social witches" [Pócs 1999: 10]. In contrast, people who break spells and heal people are known as бајачка/и, баснарка/и, народни исцелители, кушачка/и (spell-chasers, healers, fortune-tellers, conjurers, and charmers).These fall into the category of those who will go to heaven after they die. The focus of this essay will be on this latter category, the charmers, healers or spell-chasers (баснарки, баснарици, бајач/ка, кушачка).

Ways of Achieving the Position of a Folk-Healer, Spell-Chaser, Charmer

Those who are capable of "breaking" spells, and casting out disease possess qualities opposite to those who cast spells and cause disease. While those who cast spells are always women, the spell breaker could be of either gender. It was important that the person be in touch with the other side. Most women folk-healers were not of childbearing age. The research of Polish anthropologist Jozef Obrembski in 1930's in Macedonia points to this same generalization. His work took him to the Macedonian village of Volche in the Poreche region where he found out that "a true basnarica" could only be a woman who had ceased bearing children and knows how to use charms and incantations for various maladies. Even at the time of his field research, Obrembski found that the real healers and spell-chasers in Volche were scarce and that those who did exist were quite old [Obrembski 2001, I: 185; II: 55). Recent collecting conducted in the same region shows that the local population 
of this region is still familiar with the concept of "real healers" or "real charmers" and that some claim to know the names of such persons who lived in the past. None of the living residents, however, have actually met such a person, or seen them. Some informants were familiar with tools used by charmers and healers, such as deer horns, wolf's claws, wolf's teeth, horseshoes, etc., but that was the extent of their knowledge [Risteski 2002: 111-112; Risteski 2005a: 134]. A healer, it was said, could acquire her knowledge through her mother who was "her faith and her blood" [Obrembski 2001, I: 185; II: 55; Vražinovski 1989: 86; Domazetovski 132; Zlatanović 65; Radenković 1982: 12]. The transfer of power and knowledge was performed by magical actions. One such action was associated with water and the female apprentice was supposed to repeat the text of the charm on three bridges.(1) My own field research also confirms that an elderly folk healer should transfer her knowledge to a girl or a young woman who has not yet had a child of her own.(2) By comparison, in some South Slavic countries, such as Serbia, the healer transfers her knowledge to her grandchildren while they are still under the age of 10 [Zlatanović 65].

The services of the healers, spell-chasers or charmers, were paid for symbolically. However, their real reward is the prominent social positions that they achieve.(3) As with all liminal figures, the opposite can also be true and healers and charmers can be subject to censure. This is especially clear from archival materials where physical defects seem to play a determining role. Thus, people with such a defect, which was often the reason for their becoming healers in the first place, could be mocked by others in the community for doing "that", meaning practicing their healing. Their defense invariably was that God commanded them to do "it". One of the informants in the archival data divorced her husband for doing "that".(4) According to another informant, a woman changed when a female spirit (самовила) entered her body.(5)

Data found from other South Slavic countries, notably Serbia, confirms the belief that a person with a physical defect is especially prone to becoming a healer. One such example is the Serbian healer called Borko who was small, thin and had a voice as high as a child's so that people routinely made fun of him [Cvetanovska 118].(6) The Hungarians who live in Vojvodina, believed that "wise women", a term denoting women gifted with special abilities, were in close contact with supernatural forces. These women were supposed to be short, tiny and wrinkled. Their hunched backs and other physical disabilities distinguished them from ordinary people. Many of these women had 
warts on their faces or other distinctive markings. They had piercing eyes that could see through everything and were believed to be able to read people's thoughts. Many of them used canes when walking.

Real "wise women" did not take anything for their services [Penavin 77]. In some of the most recent field research the distinction between a witch "magjeshnica" and a healer or spell-chaser (бајачка, исцелителка, кушачка), no longer exists because one and the same person can cast a spell and break it. Some informants even claim that "they cast spells, and then you have to see them to break that same spell".(7) Further evidence of their double nature is the belief that healers, spell-chasers, and charmers can become vampires (вампири). According to this belief, healers are said to have had contact with impure supernatural forces during the course of their natural lives [Vražinovski 1998, I: 223]. Such is the case in Slovenia, for example, where a woman acquires the reputation of being a witch if she has been involved in healing, knows the uses of herbs, etc. According to Mencej, this is an example of the re-interpretation of white magic as an activity of witches that came about after the period of witch hunting that swept across Europe [Mencej 42]. Indeed, there is ample evidence of the attribution of opposing qualities or dual nature in the research on medieval and early modern mystics. This research shows that women's abnormal behavior can be seen as a sign of either divine or demonic possession. Furthermore, contemporary research on people in Southeast Europe today, who claim a connection to the divine or the supernatural, shows that society's attitude toward them is characterized by opposites and extremes [Pócs 2005: 127]. On the one hand they inspire respect, while on the other they provoke fear and disdain. Fear is sometimes caused by claims made by the healers themselves that the sick person must seek their services or else he will die.(8) Thus the attitude of the community towards the healer often depends on the healer him or herself and on the way that they behave towards those who turn to them for help. Typically a collective opinion is formed for each healer and, whether she will be accepted and respected or feared and disdained depends on whether that opinion is positive or negative [Vražinovski 1989: 88]. Research regarding the period following the Second World War shows that the attitude of authorities towards healers or charmers was not always understanding or sympathetic. At various times the attitudes ranged from persecution to tolerance [Vražinovski 1989: 88; Knežević 73].

Another way of attaining the position of folk-healer was by communicating with saints through dreams and visions. This path is well 
known to researchers working in other countries in Europe [See for example: Pócs 1999: 151; Pócs 2005: 126-127; Radenković 1982: 1213]. The first dream or vision typically comes when the future healer is going through a serious and intensively experienced corporal and/or spiritual crisis that leaves him or her either physically or psychologically on the brink of death or in a condition between life and death. The most frequent crises include: a long-lasting illness that persists even after all known cures had been exhausted, a coma (a condition where no life signs are evident), and deep depression that usually follows a long period of self-torture provoked by feelings of guilt and/or rejection by the community.

Researchers in Macedonia have documented several life stories of healers or charmers who gained their power when they were hopelessly ill.(9) Saint Selvija from the village of Sveta in the vicinity of Demir Hisar offers an interesting example. Despite being married for ten years, Selvija was not able to give birth. According to her story, that period was "a great burden" for her. The traditional notion that a woman must fulfill her role as mother and is complete only when she gives birth is clearly shown in the reproaches she was subjected to: "Што дека си лична, што дека си убава, кога деиа немаш!" [Your beauty is in vain, when you are childless!]. The story continues to state that because she was not able to have a child her husband stopped loving her, and started trying to force her to leave. She refused to do so as she had no other place to go. In the last four years of her "childless experience", Selvija stopped eating everything, even bread. In this period of self-starvation, she often prayed to God to give her a child, vowing that she would be his servant. One day when, in an extremely weak and depressed condition, she sat down to rest, St. John appeared at her door and instructed her to go to a certain monastery where there was healing water that would make her healthy and able to have children: "и децฺ ќе имаш и слуга ќе ми бидиш и првното моје ќ бидит" [and you shall have children and you shall be my servant and the first one shall be mine].(10) And so it happened: " $U$ јас на тоа додржив. Кај ито рече тој ојдов, се измив на водата и Господ ми даде здравје. Четири години дванаесет комули искинав од мака и така имав чупе првин. Три... две години го гледав, од врата ми го зеде капано, сторено сѐ... " [And I believed. I went where he had told me to go; I washed myself with the water and God gave me health. In my misery I had torn twelve shirts over the course of four years and finally I had a girl. I have looked after her for three . . . two years; he took her from me, bathed, tidied...](11) After having her 
children, Selvija became "weak" again until one day she fell into a coma. She was "like dead" for three days and three nights. That was the first time she visited both heaven and hell. After coming back, she started to heal and continued to heal until the end of her life [Cvetanovska 118].

The dreams and visions of folk healers follow traditional models and show a high degree of correspondence to folk beliefs about the other world and the ways one may enter it. The healer's soul is said to visit "the other world". According to Macedonian folk beliefs, the soul leaves the body and travels to "that world" at the actual moment of death. At death the soul leaves the body for good and cannot return. By contrast, when the healer's soul leaves the body, such as when he or she is in a coma or when the healer is asleep and dreaming, the soul is able to return to the body. The healer's soul retrieves knowledge from the other world and returns to complete its mission in this one. People believe that the state of dreaming and death are very similar. Death is often referred to as "the big dream", and dreaming is called "small death" [Cvetanovska $118]$.

In the mythical three partitioned structure of the world, beings from the other side are connected with the Land Above where divine beings dwell and the Land Below, the realm of the demonic and the eternal home of dead beings. The analogous Christian mythical picture includes heaven and hell. Access to these worlds involves climbing (stairs, trees, mountains) and descending (through a cave, hole). All of these are frequent motifs in the dreams and visions of folk healers. Many healers describe climbing to heaven. According to folk belief, the other world, especially the world of the dead, is separated from the human world by a large body of water. Above the water is a bridge between the reality of this side and the reality of the other side [Vražinovski 2000: 108, s.v. water]. Both natural and supernatural worlds are typically connected by a narrow bridge as "thin as a hair" over which only the righteous can pass [Risteski 1999: 123]. The life stories of folk healers frequently mention the crossing of bridges. The connection or the separation of worlds by water is a motif frequently found in dreams of a meeting with a deceased relative.(12) In some dreams the healer's soul is met by an angel, usually Archangel Michael, known among the folk as "the soul taker". According to the transcripts of M. Cepenkov, for example, when a man dies... "ангелот ја шетат душата докрај небото и докрај земјата..." [the angel takes the soul to heaven and to the heart of the earth...] [Cepenkov 1980, 9: 50]. The visions of healers or charmers who have had a near-death experience typically include an angel who shows 
the soul the bliss of heaven and the suffering of hell. The healer's depictions of heaven as a place with gardens, flowers, cheerful children, righteous people living close to God and of hell as a place with devils, cauldrons where the sinful boil eternally, dragons that eat them, are identical to folk beliefs about the other world. In the other world which, according to folk belief is the eternal dwelling place of the dead, healers are greeted by their dead relatives, an experience that serves as proof of their having accessed the other side [Cvetanovska 120].

A key scene in the narrative about the acquisition of "secret knowledge" is a meeting with a supernatural creature who orders the future healer to return to the world of the living and to start performing the task that is now his mission. Such beliefs are wide spread among all Balkan peoples [Pócs 1989: 47-48]. The supernatural beings that appear in such narratives are those to whom folk tradition, both pagan and Christian, assigns healing qualities. They are samovili, St. Petka, The Mother of God, Jesus Christ or God Himself.(13) If the person selected to receive secret knowledge rejects the mission assigned to him, he or she is punished. According to a certain informant whose wife was recently deceased, the woman died because he was a communist and did not believe in any religion. The samovila who had appeared to him supposedly inquired: “ал ке грмаваш појке против Бога", [are you still going to sin against God].(14) In another story, a woman claimed that her four children had died because she did not want to work as a healer. Finally her own life was threatened: “ако работиш сега ова јас што ти наредувам, по оваа сламка ќе поминеме, ако не работиш, да откажиш за ова, ќе те пуштиме удолу по сламката, ќе пропаднеш удолу и појке нема да бидии, а јас ке летнам" [if you do what I [God] order you to do, we shall hold onto this straw, if you do not, and if you refuse we shall push you off this straw, you shall fall down, and you shall be no more, while I shall fly away].(15) The woman accepted the mission thrust upon her, recovered from her illness, and became a healer. As a reward for the healing she did, she bore several sons.(16) In each of these cases one notices the archaic belief that certain people can be spirited away by the supernatural world. In this archaic dual system, those who go to the supernatural world, the place of death, when they are not dead themselves nevertheless belong there and so the samovila who represents death acts as their guiding spirit. These are people believed to be destined for death, or already very close to death; they are people "without status." Thus it is the quasi-dead who are initiated into the other world [Pócs 1989: 39-41]. 
One woman from the region of Poreche, village of Rechane near Makedonski Brod, was attested in J.Obrembski's research and described as "God fearing," "a holy seer." She communicated with the saints through dreams and visions. She was said to have been contacted by saints who appeared to her to express their pleasure or displeasure with the village in which she lived, with her fellow villagers and their activities and relations. Her dreams helped her to diagnose people's illnesses. She was also able to tell her clients what they had to do to get well. Her usual advice was to go to church with gifts and prayers or to seek the help of a healer. She did not charge for the services, but those who visited her left money and gifts near a little church-like structure she had built in the yard for meditation. That also was the place where she went to receive her visions [Obrembski 2001, II: 56].

Also, in more contemporary research, the healer-dreamer achieves success with the help of supernatural beings (samovili, saints) who point out the ways that the patient can be cured. These include such remedies as going to places with healing water, or using incantations, charms and amulets, visiting a doctor, etc.(17) In many cases, the healer gets information about the necessary remedy not only through consultations with supernatural beings, but also through conversations with icons. Icons seem to be used regardless of the religious affiliation of the healer [Mencej 57].

Holy seers, as they were called, were known everywhere in Europe. They were frequently described as "white witches" and, as such, were the enemies of "black witches." "White witches" worked with the help of Christian spirits and the existence of "holy healers" can be seen as the result of the increasing influence of Christianity and the resulting polarization of the supernatural world. During the Middle Ages, healers and seers became the enemies of witches. Witches, in turn, became increasingly associated with demonic forces. In this process, Christian protectors (The Virgin Mary, various Christian saints) were assigned the roles previously ascribed to ancestral guardian spirits. The importance of death, however, remained unchanged. [Pócs 1999: 153-154]. Another process was simultaneously at work. Only those people who were effective in the secular world and capable of healing a wide range of maladies were recognized as holy and ascribed the position of holy seer or living saint [Pócs 1999: 153-154]. This is clearly documented in field materials. Normal healers and charmers, as well as holy healers, are mediators and their healing capabilities are closely connected with their ability to "see" the source or cause of the afflicted person's ailment 
whether with their own eyes or through divine insight, [Pócs 1999: 153154]. The ability to see comes from supernatural forces or through the healer's close contact with the world of the dead, in other words, the other world [Pócs 1999: 156]. In our research, dreams typically indicate contact with the other world. This is especially so when the souls of the healers had to return to life by successfully navigating a narrow line such as a bridge the size of a hair or piece of straw. This condition, as mentioned above, is one where the healer comes dangerously close to death before his/her eventual recovery.

When the ability to cure is conferred upon the future healer by a relative, the importance of the other world is seen in the requirement that the initiate be a woman past child bearing age. The connection to the spirit world can also be seen in the fact that the transfer of powers is often performed on a bridge over a river, the river and the bridge being symbols of passage into the world of the spirits. Living saint-healers who were once wide-spread throughout Europe and could identify and heal evil share many of the characteristics of shamans [Pócs 1999: 155]. Links to shamanism can be seen in the more recent past in Macedonia. Here some healers fall into a trance when talking to saints or dreaming. Typically, when such a healer comes out of the dream or trance that gives her information about the ailment she is seeking to cure, she suffers a terrible headache.

\section{Charms and Incantations}

Folk healers worked with charms and incantations which, according to traditional culture, were a unique and exceptional way of healing. In the mythical and ritual perception of the folk, incantations and charms are ritual threats used to drive disease from the human body and to help the person revive and return safely to life. The actual work of healing through charms contains complementary verbal and non-verbal elements. The incantations and charms themselves can be understood as communication composed of actions and multivalent messages. Participants in the secrecy of the healing can include: a) the passive witness, i.e. the sick person, or the person who seeks help b) the transmitter/mediator, i.e. the healer or charmer who is at once the receiver of the message and a mediator between the patient and supernatural forces; c) the supernatural forces that receive the message requesting healing [Radenković 1982: 8; Vražinovski 1989: 83]. 
In the verbal rituals used by the healer or charmer, who can be either male or female, efficacy is attributed to the strength of the word. Faith in the strength of the word was characteristic of the majority of IndoEuropean peoples [Dmitrieva 119] and the power of speech was used to expel disease to spaces which were believed to be alien to man. They were spaces that were not culturally conquered and thus outside the village community. Space that is on the border of the social and sacred is considered to be deserted and dead. In fact, the expelling of the impure forces, meaning disease, through incantations and charms is based on the notion of disrupting the border between the social (human) and inhuman worlds [Radenković 1982: 26; Radenković 1996: 49]. For this reason, the healer tries to send the disease into spaces that are connected firstly with roads, and then into places that denote the other world, the world of the demonic beings. The power of borders explains why charms or incantations are recited mostly at crossroads, a place where demonic beings are generally believed to gather. The verbal declarations clearly show that the disease is cast off into a world where humans are not present. Most frequently these unhealthy, lifeless communities are described as villages without roosters, where no dogs bark, no cats meow, literarily, villages which have been abandoned.

“До сега беше заградено, сега m'одградујеме.

До сега беше заорано,

сега т'одорујеме...

Ојси преко девет планини,

Преко девет конаци...”

[Obrembski 2001, I: 206]

“Да си појдиш високи планиње,

Кај ито деиа не се критеваат,

Кај ито невести не се венчаваат,

Кај ито луѓ не се миросуваат,

Тамо имат трева зелена,

Тамо имат вода студена,

Тамо имат мека постела..."

[Cepenkov 1972, 9: 408].

"Поможи му Господи,

И си светии небесни,

И вие мои бестсребреници,

Да ја испратам болеста,

Од ова мачна душа,

Со колак и со бардаче,

И со голем бакшиш кошула,
[Until now you were fenced, now we release you to go

Until now you were ploughed, now we let you go...

Go away over nine mountains, Over nine inns...]

[You go to high mountains, Where children are not baptized,

Where brides are not wed, Where people are not anointed, The grass is green there, The water is cold there, The bed is soft...]

[Help him God And you heavenly saints, And you my silverless To see the illness go away From this darkened soul, With a bread " kolak" and a drinking vessel And with a shirt as a gift 
Да си оди на туѓа туѓина,

Преку девет мориња,

И преку деведесет и девет планиье" And across ninety-nine mountains..] [Cepenkov 1972, 9: 289].

"Бегајте надворитиње, Од оваа мачна душа,

Оти секогаш кंе ве чадам, Со оваа лоча миризба, Да појдите во гора зелена, Кај Гургі́ самовила, Под таа сенка ладовна, До таа вода студена, Смилени китки да китите, Венции на Ѓррѓa да праите. Ако неќите тамо да појдите, Појдите во некоја куќа богата. Тамо пола да праите, И в душеии од пердув да лежите." [Cepenkov 1972, 9: 300].

“Оди у Лелек Гора, у Неврат Поле,

Каде петел не пејет, каде говеда не рикаат,

Каде пес не лајет, каде мачка не маукат,

Каде овизи не блекат,

Каде чрква немат, каде камбана се не слушат...

Ти изгорев деиата, ти изгорев вујка ти

Баба ти, ти изгорев вујна ти

Татко ти, ти изгореф кумот ти

Мајка ти, ти изгорев кумата

Стрика ти, ти изгоред брата ти

Стрина ти, ти изгорев снаа ти

Тетина ти, ти изгорев зета ти

Тетка ти, ти изгореф сестра ти.

Те изгореф, те испржив,

Ти изгорев сва твој род.

За тебе немаш корен,

Траг ти се не видел,

Семе ти се сотрело, до века и увек.

Помози ми Господе, сине Божји,

Душа свети и поможи ми мајко, Богородище”!

[Go to the Moan Forest, to the Never land,

Where no roosters crow, where no cattle bellow,

Where no dogs bark, where no cats meow,

Where no sheep bleat,

Where there is no church, where no bells toll...

I burned your children, I burned your uncle

Your grandmother, I burned your aunt

Your father, I burned your godfather
[Go away you, apparition, From this darkened soul, To make it go away Across the nine seas ways put smoke into you, With this foul smell, You go to the green woods Go to the Samovila Gjurgja, Under that cool shadow, Near that cold water, You decorate nice bouquets, And make wreaths for Gjurga. If you do not want to go there,

Go to a rich house.

And there you do your thing, and on feathery mattresses you lay.] 
Your mother, I burned your godmother

Your uncle, I burned your brother

Your aunt, I burned your sister-in-law...

I burned your whole family.

You have no roots

No trace of you will be left

Your seed be damned for eternity.

Help me Lord, son of God.

The souls of the saints and help me Mother of God!]

[Obrembski 2001, I: 207]. (18)

From the above examples it is clear that the verbal formulae send diseases to places that were seen as far away. These places were associated with the other world. They were places where no one could travel and from which there was no return. Places such as Moan Forest and Neverland, for example, are locations where there are no attributes of human culture or symbols of a healthy community bustling with life. As above, they are villages without roosters, where dogs do not bark, cats do not meow, where there is no church and bells do not toll, where children are not baptized, where brides are not wed. (19) In one charm, a healer addresses the moon to cure a sick child. She holds the child in her hands and says: "На ти што ни даде месечино, дај ни ито ни зеде!" [Moon, I take what you have given us; give us what you have taken from us].[Cepenkov 1972, 9: 278].

Using metaphors of open and closed borders to create systematic models of disease and the human body is a widely known practice [Kamppinen 11,50]. On occasion, the other world is described as better than the one the ill person occupies and the illness is urged to go to this more attractive realm. Another attribute of the mythical realm is silence, meaning that the other world is seen as a deserted place.(20) The magical power of silence and death can be seen in an Albanian example. A sick child was taken to the grave of an unknown person and left there. It was believed that if the child started to cry he would survive and, if he did not, he would die.(21) Unknown graves as magic places are widely attested among Macedonians who practice throwing objects on them or simply adding the magic formula "As I do not know who lies in this grave" to their charms [Cepenkov 1972, 9: 284-285; Vražinovski 1998, I: 219].

There are traces of charming among the eastern Slavs who practice whispering followed by a shaman-like trance [Radenković 1996: 31]. In cultures where people use magic analogies, where every subject, appearance and object in the environment is considered to be alive, the 
disease itself is often burned to kill the root of the evil. [Risteski 2002: 115; Risteski 2005a: 137]. Research on Slavic, Balkan, and some IndoEuropean peoples which documents the expulsion of impure forces shows that these forces are sent to forests, mountains, waters, seas, distant lands, rocky areas, heights, certain unpopulated places, and so forth. All of these are wild and strange places. The models, then, are built on the binary oppositions: near/far, one's own / other's, to which the oppositions below/above, shallow/deep, narrow/wide can be added [Radenković 1996: 53, 75; Fabijanović 1989: 71-73].

The non-verbal component of charming includes actions, objects, and movements. These function to reinforce the mythical ideas of threatening and expelling. Once a disease has been expelled, the healer or charmer offers the breath of new life. Here the primary concern is the human body. Both the body of the healer or charmer and that of the ill person are involved. In magic and religious texts, and also in healing practice, the body is understood as a spatially organized whole whose parts hold symbolic meaning. Thus, certain parts of the body become signs which reveal mythical content [Radenković 1996: 9]. Here I refer to the expulsion of the illness from the head to the hands, the stomach, and finally to the legs and the feet. This ritual activity is a clear sign of the spatial definition of the human body in traditional cultures, where the head is the highest and peripheral point, and this is why the process of curing should start from there. In this sense, the legs and especially the feet have a contrary meaning: they are the lowest peripheral parts but, since they are closer to the ground, they connote a higher degree of contamination and provide the possibility of expelling the disease through them. Once illness is expelled, rituals of blowing, tying, boiling water, passing the patient through an opening are often used to signify the rebirth of the patient.

Cures which expel illness from the body by directing it through proper channels and helping it exit the patient are known almost everywhere in modern Europe. The formal characteristics of these cures and the verbal formulas used may indicate a relationship with past beliefs in demons [Pócs 2005: 105-106]. Thus, in the Macedonian region of Zeleznik, people who experienced a nervous breakdown or were frightened by something were said to "get the fright" or have fear sickness. To cure this condition, healers put some flour and salt in their hands, placed them on the head of the ill person, and blew into the salt and flour, saying: 
"Пречиста на глава,

Ристос на гради,

Богородица на срие,

Уплав под нозе!...

Ке одврзам веторитина

Во гора зелена

Кај ито петел не пее

Кај што секира не сечит,

Тамо има чешма шарена

Ем да пиет, ем да спиет”.
[The Immaculate on the head,

Christ on the chest,

Mother of God on the heart, the fright under the feet! ..

I shall ward off the winds, into a green wood,

Where no rooster crows, Where no axe cuts,

There is a dappled well, to drink from and to sleep by].

Others healed by using nine hot horse and donkey shoes, found along the road. They would hold a shoe near the inflicted person's forehead, then his chest, his knees and so forth. They would then cool the hot shoe by dipping it into water in a vessel placed at the feet of the patient. As they did so they would say: "Ристос на чело,/ Богородииа на гради, /уплав под нозе!" [Christ on the forehead,/ Mother of God on the chest,/ the fright under the feet!] The healer or charmer gave the ill person a drink from the water in the vessel and then poured the rest in a place where no other person could tread. This precaution prevented others from contracting the illness. [Krsteva 126-127].(22) In this kind of incantation or charm, the binary opposition of above/below is prominent. Besides this opposition, another distinction can also be noted, namely the one which divides the body horizontally into right and left. The right side is associated with good and is connected to the male side, while the left side is associated with the bad, evil, or female side. This dichotomy means that healing is usually done with the left hand because of the need to communicate with impure forces [Radenović 1996: 23; Krsteva 111]. The right/left dichotomy also means that, when healing is done near a windmill, it must be a mill where the stone turns to the left or counterclockwise. Similarly, the magic objects found in the house are thrown into a whirlpool in a river and it must be a whirlpool that spins to the left. [Radenović 1996: 70; Cepenkov 1972, 9: 292; Marinov 151; Arnaudov 41].

A very efficient healing technique, one that involves discovering the woman who had cast a spell or performed malevolent magic, was to use the ligaments taken from the front paw of a wolf.(23) The wolf is important in healing practices because of his symbolic status among animals. He is considered the guardian of the border with the wild and, as such, he is the fiercest enemy of impure forces and various maladies. He must guard the border because impure forces constantly cross it, violating the division that, according to myth, was determined at 
creation. His protective role is also evident in beliefs held by Macedonians and some other South-Slavs. According to these beliefs, "vampires" and some other "demonic creatures" can be destroyed by summoning the wolf. The wolf's place in Macedonian charms and incantations is important. Parts of the wolf's body were given to pregnant women as protection from evil forces. They were also given to fearful children, meaning those suffering fear sickness. Often the curing of such a child involved threatening the illness afflicting him or her by calling on an angel or a wolf. Afterwards, the child was passed through the mouth of a wolf skull.(24) This latter practice is analogous to other types of passing through openings attested among other South Slavic peoples [Radenković 1996: 91-97].

To sum up, the cultural code requires that the act of curing contain a ritual threat, expulsion of the disease from the body, the destruction of the disease, and then the consolidation of the body, the revival of the patient and his return to life. This is the starting point for understanding the following, namely that studies of the ritual behavior of healers and charmers during conjuring and expelling diseases have shown that several used the techniques of blowing, tying, and drawing or passing the patient through an opening. Blowing can be connected to the archaic motif of the breath of life. It can be seen as revival, expressed through the motif of the soul as the essence of living beings.(25) Thus, the ritual of blowing towards or into the ill person, or expelling disease through protracted and intensive ritual yawning and shouting can mark the process of breathing life into the patient. After the charmer or healer expels the disease, he/she blows three times in the area of the ill person's mouth or head or on the painful part of the body. This is clearly analogous to the primordial act of God breathing life into man; it is literally the same as breathing a new soul into a person to give him life, health, and mobility. Therefore, the act of ritual healing brings the charmer close to exceptional holiness. When she or he assumes the position of a creator of life, the giver of a new soul, she or he is similar to the Divine; his or her action is akin to one when God created man [Risteski 2002: 118; Risteski 2005: 86].

The technique of tying the disease [Schubert 143-146; Radenković 1982: 266; 419) is wide spread in ritual. By using the analogous action of tying knots in woolen yarn, the healer can tie or bind the disease and make it ineffective. " $Ј а$ ке те врза света лошотија,/ тује да останет, тује врзана да седит,/ тује да пијет, тује да јадет..." [I will tie you, you holy evil,/ to stay here, to stay tied,/ to drink here, to eat 
here...]. [Obrembski 2001, I: 170]. This type of ritual and magical act is performed after the healer transfers the disease to the ill person's garment. The garment with the disease is then bound to a special place designated for that purpose which is usually the sweetbrier. This frees the sick person from his illness. Sometimes knots were tied into the cord used to tie down the body during rigor mortis. This was accompanied by the formula: "Како што го врзав јазолов на конецот од пустите ништи, така да се врзат сите болести ито ке му идат оваа година на стариот" [As I have tied the knot in the cord from the damned so let all diseases that will come to the old one tie themselves up...]. Afterwards, the cord was buried under the doorstep of the house. [Cepenkov 1972, 9: 287].

Another wide-spread technique is drawing or passing the patient through an opening; this is a symbolic death and rebirth. Frequently, a rock or tree is used as the object through which the afflicted is passed. The rock, typically with a hole in it, or a tree such as one that has been split or one where there is a hole under the roots that a person can pass through, signifies the border between two worlds. There are documented instances of healers pulling sick children through rocks or tree roots,(26) or passing them through the mouth of a wolf's skull. Also, in Macedonia, this type of healing is used for women who cannot have children.(27) When expelling the problem, the charmer or healer uses certain tools to mythically or symbolically threaten and expel what troubles the patient. These include herbs whose characteristics represent power against demonic forces.(28) Among such herbs and other plant substances are basil, various thorns, and assorted seeds. Often, sharp metal objects such as knifes, axes, and sickles which have the power to cut and destroy impure forces are used. Fire and the tools connected with it are also employed [Radenković 1982: 9].

\section{Conclusion}

Based on the above observations, one can deduce that the secret knowledge of experts in magic, notably their charms, incantations and the actions that accompany them, are an archaic remnant of folk magic medicine [Kulišić, Petrović \& Pantelić 16, 77]. In certain communities, these practices persist today. Due to the fact that charming represented a unique and an extraordinary form of healing, the folk healers and charmers were mostly highly respected in their communities. Healers and charmers had their own, special place in society. They enjoyed a special 
status and formed a special subculture [Risteski 2002: 120]. But sometimes they were seen in a contrary light and people who could heal were also accused of causing illness. Mostly, however, people who had dreams and visions and were able to communicate with supernatural beings were seen as saviors who could solve the existential crises of individuals and the community. The dreams and visions were also retold by people with open excitement and used to enrich the folk perception of and beliefs about the other world. Such perceptions can be found in legends and magical stories about heroes who descend to the Land Below or climb up to Heaven and gain insight into another reality [Šapkarev 156; Cepenkov 1980, 4: 48]. Beliefs connected to the visions of healers and charmers can also be found in apocrypha which, according to scholars such as Stojčevska-Antić, were wide spread and had an important influence on Macedonian folk creativity [Stojčevska-Antić 17, 81,185]. Finally folk healers offer the people of the community personal insight into the other world, especially the world of the dead. As such, they provide "evidence" for the continuity of life. They confirm and strengthen faith in immortality which is fundamental to any religion [Cvetanovska 121].

The secret knowledge of spell experts and healers can be connected with death or the being owned by death [Pócs 2005: 93]. This deeply archaic belief is evident in how knowledge is acquired, namely that it is passed on from mother to daughter or granddaughter/grandson in a place that suggests connection to the other world (water, bridge). It is also evident in the fact that the women performing charms must be postmenopausal. Also important is the fact that, when knowledge is acquired through dreams and visions, the soul of the initiate or the initiate him- or herself must be in touch with the other world and then return to life by passing over a thin line: a bridge as wide as a hair or a straw. This is a condition akin to death followed by eventual recuperation. Part of the archaic structure is the time and the spatial symbolism used in charms. Evidence here includes the idea of the illness being sent out of the human body, from the head on down to the feet. It includes the places that designate the other world (Neverland, Moan Forest, places where no roosters crow, where no dogs bark, etc.). The time when charms are performed is also important: it is an "other worldly time," while the place is typically liminal: a symbolic circle on the doorstep, on a grave, or an opening through which the patient can pass enacting a symbolic death and rebirth [See more about the time and space in charms and incantations in: Radenković 1982: 8-9]. An important principle is for the 
healer to have a relationship with death, one that is gained from supernatural beings (samovili) or Christian saints, angels, or even God himself. Illnesses are expelled to wild and deserted places and this model is based on the binary opposition of near/far, one's own/someone else's, to which the additional oppositions of below/ above, shallow /deep, narrow/wide can be added. Usually the second member of the binary opposition holds negative connotations.

\section{NOTES}

1 Thus for example, the old woman would take the young one to a river or to a place near water. Over the water, the young woman would take the braids of the old charmer in her hands and would listen to the words the latter said. After that, the young woman had to silently repeat the learned text three times on three bridges and three times while at a church mass [Krsteva 106].

2 Archive of the Institute of Folklore "Marko Cepenkov," in Skopje (hereafter: AIF), tape no. 3870, informant D. M.(f), born 1925 in village Mozdivnjak (Kriva Palanka), lives in v. Psacha (Kriva Palanka). Recorded by: Vesna Petreska in v. Psacha in 2000. (Further: AIF, t. no. 3870, inf. D. M. (f) b.1935 in v. Mozdivnjak (Kriva Palanka), lives in v. Psacha (Kriva Palanka).

3 J.Obrembski's research in Macedonia, in the village of Volche, shows that the woman-healer received privileges that belonged only to men. She did not have to stand up while greeting men. At public meetings, like weddings, she could freely mingle with men, sit at their table, drink brandy with them, and talk with them as their equal, and if she wanted, she could even use foul language, which was restricted to the male domain [Obrembski 2001, II: 56].

4 AIF, t. no. 2885, inf. M. T. (f) from v. Kanatlarci, area of Prilep, b.1934 in v. Pashino Rufci (area of Prilep). Recorded by: Tanas Vražinovski.

5 AIF t. no.2885, inf. S. D. (m). Recorded by: Tanas Vražinovski in 1982. This woman was the informant's sister. Before that time she interacted with people, she was cheerful, ate everything, but since the spirit ("самовила") entered her body, she became restricted in communication with people, did not go to festivities, did not share jokes, did not eat everything. It is believed that such women do not live long. This woman with "the samovila inside her body" lived for five more years. According to the informant, after death, the samovila goes to 
heaven, while the woman follows as her servant. Also other field research confirms that the people who had samovili enter their bodies became good people and did only good deeds. They received healthy power and were capable of "breaking" spells and conjuring. According to belief these people did not live long, usually 5-6 years. After death both the people and samovili go to heaven, but the people become servants of the samovili. (Vražinovski, 1998, I: 169, 174).

6 Cited according to: J. Tucakov, Psychosuggestive elements in folk's medicine of Svrljiski Timok, Belgrade, 1965, 10-13. The news that this healer was selected to heal the people was announced to him by St. Petka, after six months of torture (he could not eat, sleep, or perform his marital duties; he only sat on a chair in a constant trance). Immediately after the experienced vision, Borko bathed himself in water in which there was basil and he recovered.

7 My own field research.

8 My own field research.

9 AIF t. no. 2885, inf. M. T.(f); S. D.(m); Gj. B. (m). Recorded by: Tanas Vražinovski in 1982 y.; AIF t. no. 2935, inf. S. O. T. (f) b. 1900. Recorded by: Tanas Vražinovski in v. Sveta - Demir Hisar in 1981; [Cvetanovska 117-122; Vražinovski 1989: 86; Domazetovski 132].

10 AIF t. no. 2935, inf. S. O. T. (f); b. 1900. Recorded by: TanasVražinovski in v. Sveta - Demir Hisar in 1981.

11 AIF t. no. 2935 , inf. S. O. T.

12 My own field research.

13 In archive materials we find data that a certain woman, a sister of the informant, managed to fulfill her healing tasks with an icon. According to the informant, a samovila had entered his sister's body. When she, as a healer, would place an icon on the afficted body part of the man / woman believed to be the victim of magic, the samovila would tell her the way to cure the problem. In this case we can clearly see the syncretism of pre-Christian and Christian beliefs (it is a samovila that is inside the body, while the healing is done with an icon). The informant told of another case involving a man from the village of Izvor, area of Prilep, who "saw" with the help of a saint. The man fell into a kind of "trance" and he appeared to be sleeping when he communicated with the saint who told him how to heal. AIF t. no. 2885, inf. S. D.(m). Charms using icons were also found by M. Cepenkov [Cepenkov 1972, 9: 404407]. This type of healing is well known in Macedonian healing practices. An example is the healer (“бајач”) Vasilko, in the Macedonian region of Poreche, from the village of Krapa. He obtained his knowledge 
when he supposedly lived for six weeks in a liminal state, suspended between life and death, in the hills and forest. When he awoke from this state, he became a seer. He responded to people's questions and supplied them with solutions after speaking with icons [Mencej 57].

14 AIF t. no. 2885, inf. Gj. B. (m); b. 1927 in v. Jablanica - area of Struga. Lives in v. Kanatlarci - area of Bitola. Recorded by: Tanas Vrazinovski in 1982.

15 AIF t. no. 2885, inf. M. T.(f)

16 AIF t. no. 2885 , inf. M. T.(f)

17 AIF t. no. 2885 , inf. M. T. (f)

18 Similar examples, see: Radenković 1982: 70-71; 75-76; incantation no. $94 ; 102$.

19 For similar examples from the Southern Slavs see: [Radenković 1982].

20 Note the ritual dances with masks which in Macedonia were performed for the period of the winter solstice, from Christmas Eve until Gjurgjovden (St. George) and Spasovden. The intensity of these dances was greatest in the period of the so called unbaptized days from Kolede (January 5) until Twelfth Night (January 18). The dances were performed on the eve of Vasilica (January 13), and that period was believed to be rife with impure powers. Protection from impure powers required making a terrible noise (drama games, bells, singing songs with erotic content, etc.).

21 My own field research.

22 For the expulsion of the illness from the head to the legs, see: [Cepenov 1972, 9: 286].

23 The procedure was performed at night; a fire was set up on a crossroad and a clay pot was left over the fire to get hot. After that the wolves' ligaments were put inside. The heat caused the ligaments to expand until they burst. When throwing the ligaments inside the pot, the names of women suspected of doing magic were recited. The sorceress was rendered ineffective when the ligament burst as this was considered to be the annulment of the magic [Obrembski 2001, I, II: 168-169; 72-73; Cepenkov, 1972, 9: 289].

According to J.Obrembski's research in the Macedonian area of Poreche, in the village of Volche, this conjuring practice was not performed often because there was danger for the performer and his family if the charm was not recited properly. According to a folk saying "it was a great sin then to burst ligaments", and the women always pointed to other ethnic groups that did this, for example, Gypsies. 
Obrembski, however, learned the real significance of this practice when the man of the house where he was staying caught a wolf. The man was very proud of the catch and ligaments he possessed, and he did not even hide the fact. He said: "Let some of them dare and try to make magic; I will burst their veins". He was triumphant because he expected financial benefit from the sale of the wolf's body parts (the jaws, eyes, claws, rump, ligaments) [Obrembski 2001, II: 95-99]. It appears that bursting wolves' ligaments was used more as a means of prevention, as a sanction that threatened sorceresses, and not as a way to solve problems. Consider, for example, that the charmer had to know the whole technique in order to perform the ritual, otherwise she would put herself and her family in great danger. Furthermore building a fire in the dead of night on a crossroad opens the possibility that she may be seen, and the rule says that she must not be seen. Finally, it is believed that this blowing/ bursting was performed by women from a different ethnic group, namely Gypsies. By the same token, when Obrembski was doing his research in the area of Poreche, he did not meet any Gypsies. This makes it clear that this procedure was not used.

24 We find examples that belief in the power of the wolves' organs was wide spread and documented in the works of Macedonian scholars working at the beginning of the 19th century. Their work show that such acts were condemned: "I see some put garlic on their heads, some have taken a tooth from the wolf, the others have taken its heart, and they carry it as a light.... What is this disbelief in you? What is this polytheism in you? What is this madness at old age? If the wolf could have taken care of the man, everyone would have kept a live one at home." [Krčovski-Pejčinović 75-76].

25 This is the universal cosmogenious motif, namely that the creation of man is the result of the battle between God and the Devil. In Macedonian folk belief God and the Devil were once brothers. According to legend, each made a man of dirt, only God managed to breathe a soul into him, to bring the man to life by blowing three times into his mouth. The man made by the Devil, however, remained a piece of dirt. See: [Vražinovski Folk mythology of Macedonians, 1998, I, p.15; Lafazanovski 31-32].

26 In the area of Zeleznik, children suffering from hernias were passed through a tree whose root was split into two parts but joined again to form an opening. The women pulled the children through the opening three times and on the tree they left a dirty diaper from the sick child. A very frequent practice was to pull a child through the roots of an oak or a 
walnut tree. Usually the child was taken there by a woman who had stopped bearing children. The old woman dug beneath the root of the tree and pulled the child through three times. A shirt, a scarf or some other cloth item was left behind [Krsteva 107].

27 In the same area of Zeleznik, women who could not have children went to pass through rocks in the village of Koshino, in the vicinity of Krushevo. There was a huge rock with two openings called the "male rock" and the "female rock". The woman entered through "the female rock" and exited through "the male rock". She did this three times [Krsteva 130]. "Govedar Kamen" a place near the town Sveti Nikole, where women who could not have children go to pass under the rocks is also famous. [See: Petreska 2005: 128-129; Petreska 2006:171-172; Karadzoski 85-86].

28 The use of plants in magical practices and healing has been extensively discussed. See [Kolosova 47-64; Čajkanović, 1985; the journal: Kodovi slovenskih kultura, and the journal: "Plants", number 1, Beograd, 1996]; for plants among Albanians, see: Peterson-Bidoshi 78116.

\section{LIST OF INFORMANTS CITED IN THE ARTICLE}

Gj. B. (m) born 1927 in v. Jablanica - area of Struga, lives in v. Kanatlarci, area of Bitola.

S. D.(m) lives in v. Kanatlarcu - area of Prilep

D. M. (f) born 1935 in v. Modzdivnjak - area of Kriva Palanka, lives in v. Psacha - area of Kriva Palanka.

S. O. T. (f) born 1900 in v. Sveta - area of Demir Hisar.

M. T. (f) born 1934 in v. Pashino Rufci - area of Prilep, lives in s. Kanatlarci - area of Prilep.

\section{BIBLIOGRAPHY}

Arnaudov, Mihail. 1930. Арнаудов, Михаил. “Фолклорни приноси от Родопско" [Folklore materials from Rodopies], Сборник за народни умотворения и народопис, XXXVIII, София.

Cepenkov, Marko. 1972. Цепенков, Марко. Македонски народни умотворби [Macedonian folk works], book 9, Skopje.

Cepenkov, Marko. 1980. Македонски народни умотворби [Macedonian folk works], book 4; book 9, Skopje. 
Cvetanovska, Jelena. 2001/2002. Цветановска, Јелена. "Искуство блиску до смртта како влез во натприродното" [Near-death experience as the entrance to the supernatural]. Етнокултуролошки зборник VII(Svrljig): 117-122.

Čajkanović, Veselin. 1985. Чајкановић, Веселин. Речник српских народних верована о биљкама [Dictionary of Serbian Popular Beliefs about Plants]. Belgrade: Srpska kniževna zadruga.

Dmitrieva, I.S. 1984. Дмитриева, И.С. "Народные представления о болезня и отражение их в русском фольклоре (сравнительно с фольклором Южниых Славян" [Folk notions about Illnesses and their Reflection in Russian Folklore (Viewed Comparatively with South Slavic Folklore)], Македонски фолклор 33: 119-126.

Domazetovski, Petko. 1989. Домазетовски, Петко. "Вражењето и баењето во областа Дримкол, Струшко" [Fortune-Telling and Magic in the Region of Drinkol, Struga, and its Surroundings], Македонски фолклор 44: 129-148.

Fabijanović, Radmila. 1989. "Egzorcizmi u etnički homogenim i etnički heterogenim sredinama (na primeru nekih balkanskih naroda)" [Exorcisms in Ethnic Homogenous and Heterogeneous Environments (Examples of Some Balkans peoples)], Македонски фолклор 44: 69-76.

Kamppinen, Matti. 1989. "Cognitive systems and cultural models of illness. A Study of Two Mestizo Peasant Communities of the Peruvian Amazon," FF Communications 244, Helsinki: Suomalainen Tiedeakatemia Academia Scientiarum Fennica.

Karadzoski, Vladimir. 2001/2002. Караџоски, Владимир. “Исцелителската моќ на Говедаровиот Камен” [Healing Power of the Stone of Govedar], Етно-културолошки зборник VII(Svrljig): 83-87.

Knežević, Srebrica. 1985. Кнежевић, Сребрица. "Враћ, хећим, лекар личност која се истиче и одваја" [Conjuror, Hecim, Folk Doctor an Outstanding Person], Македонски фолклор 36: 65-74.

Kolosova, B.V. 2005: "Name-Text-Ritual: The Role of Plant Characteristics in Slavic Folk Medicine," Folklorica: Journal of the Slavic and East European Folklore Association X(2): 47-64.

Krčovski-Pejčinović. 1963. Крчовски-Пејчиновиќ. Избрани тексови [Selected Works]. Preface: Blaže Koneski (Блаже Конески). Skopje. 
Krsteva, Angelina. 1987. Крстева, Ангелина. "Народната медицина во Железник" [Folk medicine in Železnik], Македонски фолклор 3940: 103-132.

Kulišiš, Špiro; Petrović, Ž. Petar; Pantelić, Nikola. 1970. Кулишић, Шпиро; Петровић, Ж. Петар; Пантелић, Никола. Српски митолошки речник [Serbian Mythological Dictionary]. Beograd: Nolit.

Lafazanovski, Ermis. 2000. Лафазановски, Ермис. Македонските космогониски легенди [Macedonian Cosmogonic Legends]. Skopje: Kultura-Skopje, Institute of Folklore "Marko Cepenkov."

Marinov, М. 1914. Мариновъ, М. Народна вяра и религиозни народни обичаи [Folk Believe and Religious Folk Customs]. Сборник за народни умотворения и народопис, XXVIII. София.

Mencej, Mirjam. 2005. "Witchcraft in Eastern Slovenia and Western Macedonia - a Comparative Analysis," Post-Yugoslav Lifeworlds. Between Traditions and Modernity. Ljubljana 37-67.

Mencej, Mirjam. 2001. Македонски етносоичолошки студии [Macedonian ethnosociologic studies], book II, Editor and translator: Tanas Vražinovski (Танас Вражиновски). SkopjePrilep: Institute for old Slavic culture - Prilep: Matica Makedonska. Obrembski, Jozeph. 2001. Обрембски, Јозеф. Фолклорни и етнографски материјали од Порече [Folk and ethnographic materials from Poreče], book I, Editor: Tanas Vražinovski (Танас Вражиновски), Prepared by: Tanas Vražinovski (Танас Вражиновски), Sonja Jovanovska (Соња Јовановска), Vladimir Karadzoski (Владимир Караџоски). Skopje-Prilep: Institute for old Slavic culture - Prilep: Matica Makedonska.

Penavin, Olga. 1985. "Narodno lečenje kod Mađara u Jugoslaviji” [Folk cures among Hungarians in Yugoslavia], Македонски фолклор 36: $75-82$.

Peterson-Bidoshi, K. 2006: "Qazim Shemaj's' 'Veronica's Dream": A Contemporary Albanian Fairytale," Folklorica: Journal of the Slavic and East European Folklore Association XI: 78-116.

Petreska, Vesna. 2005. Петреска, Весна. Систем на сродство кај Македониите [System of Kinship among Macedonians].Skopje: Institute of Folklore "Marko Cepenkov", Special editions, Vol. 69.

Petreska, Vesna. 2006. “Духовното сродство во современите општествени процеси" [Spiritual Kinship in Contemporary Social Processes], Македонски фолклор 63: 163-179. 
Pocs, Éva. 1989. "Fairies and witches at the boundary of South-eastern and Central Europe," FF Communications: 243.

Pocs, Éva. 1999. Between the Living and the Dead. A Perspective on Witches and Seers in the Early Modern Age. Budapest: CEU Press.

Pocs, Éva. 2005. "Possession phenomena, possession systems. Some East-Central European Examples," in Communicating with the spirits. Demons, Spirits, Witches, ed. by Gábor Klaniczay and Éva Pócs, in collaboration with Eszter Csonka-Takáa, Vol. I. BudapestNew York: CEU PRESS, 84-151.

Radenković, Ljubinko. 1982. Раденковић, Љубинко. Народне басме и бајана $a$ [Folk Incantations and Sorcery]. Niš-Priština-Kragujevac.

Radenković, Ljubinko. 1996. Раденковић, Љубинко. Симболика света у народној магији јужних Словена [World Symbolics in Southern Slavic Folk Sorcery]. Niš-Beograd: Prosveta - Niš, Balkanološki Institut - SANU, Beograd, Special editions, book 67.

Risteski, Ljupčo. 1999. Ристески, Љупчо. Посмртниот обреден комплекс во традициската култура на Мариово [Posthumous ritual complex in the traditional culture of Mariovo]. Prilep.

Risteski, Ljupčo. 2002. "Народните исцелителки во Порече од времето на Јозеф Обрембски до денес" [The folk healers in Poreche from the time of Joseph Obrembsky up to the present], International Scientific Assembly Samokov, 14-16 September 2001, 70-Years from the research of Joseph Obrembsky in Poreche, $R$. Macedonia. Institute for old Slavic culture - Prilep, 111-120.

Risteski, Ljupčo. 2005. Категориите простор и време во народната култура на Македониите [The categories of space and time in the folk culture of the Macedonians]. Skopje: Matica Makedonska.

Risteski, Ljupčo. 2005a. "Traditional Healers in Poreče from the Time of Jozef Obrembski to the Present Day," Post-Yugoslav Lifeworlds. Between Traditions and Modernity. Ljubljana. 133-141.

Schubert, Gabriella. 1984. "Konac, vrpce i tkanina kao magisjka sredstva narodne medicine u Jugoistočnoj Evropi" [Yarn, laces and textile as a magical means in the folk medicine in South-eastern Europe], Македонски фолклор 33: 135-151.

Stojčevska-Antić, Vera. 1996. Стојчевска-Антиќ, Вера. Апокрифи, предговор, избор, белешки и редакција [Аpocrypha, preface, selection, notes and editor]. Skopje.

Šapkarev, Kuzman. 1976. Шапкарев, Кузман. Избрани дела [Selected Works], book 5, Ed. Tome Sazdov. Skopje: Misla. 
Tucakov, J. 1965. Туцаков, Ј. Психосугестивни елементи у народној медииини Сврљишког Тимока [Psychosuggestive Elements in the Folk Medicine of Svrljiski Timok]. Beograd.

Vražinovski, Tanas. 1989. Вражиновски, Танас "За некои ликови на бајачки и нивниот раскажувачки репертоар" [About Some Charmers and Their Story Repertoire], Македонски фолклор 44: 83-88.

Vražinovski, Tanas. 1998. Народна митологија на Македонците [Folk Mythology of Macedonian]. Assistants Ljupčo S. Risteski (Љупчо С. Ристески), Vladimir Karadzoski (Владимир Караџоски), Lola Simoska (Лола Симоска). Skopje-Prilep: Institute for Ancient Slavic Culture - Prilep: Matica Makedonska.

Vražinovski, Tanas. 2000. Речник на народната митологија на Македониите [Folk mythology of the Macedonian People], ed. Tanas Vražinovski (Танас Вражиновски), Prepared by: Tanas Vražinovski (Танас Вражиновски), Sonja Zogović (Соња Зоговиќ), Vladimir Karadzoski (Владимир Караџоски), Sonja Jovanovska (Соња Јовановска), Biljana Ristovska-Josifovska (Биљана Ристовска-Јосифовска). Prilep-Skopje.

Zlatanović, Momčilo. 1989. "Basma i bajanje danas" [Charms and charming today], Македонски фолклор 44: 65-68. 